\title{
14
}

\section{National IT Initiatives and Development - The Malaysian Experience}

\author{
M. Kamsah
}

Dept. of Maths and Computer Science, University of Salford M5 4WT, United Kingdom

E-mail : M.Kamsah@mcs.salford.ac.uk

tel : +441618394139

\section{S. Mokhtar}

Faculty of Computer Science and Information Technology

University of Malaya

50603, Kuala Lumpur, Malaysia

E-mail : salimah@fsktm.um.edu.my

\section{A.T.Wood-Harper}

Dept. of Maths and Computer Science, University of Salford M5 4WT, United Kingdom

E-mail :atwh@compuserve.com

\begin{abstract}
This paper reviews the Malaysian approach in developing and implementing IT initiatives in the creation of information-rich society in the country. It also addresses various issues that have to be faced by a developing country in positioning itself towards achieving a fully-developed status nation by the year 2020 .
\end{abstract}

\section{Keywords}

IT initiatives, technology adoption, Malaysia, Vision 2020, Multimedia Super Corridor 


\section{INTRODUCTION}

Vision 2020 was unveiled by the Honourable Prime Minister of Malaysia on February 28, 1991 during the inaugural meeting of the Malaysian Business Council (Vision2020, 1991) Vision 2020, whose mission should be fully understood by all Malaysians, reflects the vision of a fully-developed and industrialised Malaysia by the target year 2020. It is essentially a long-term vision containing broad policy directions encompassing various aspects. The main aim of Vision 2020 is as clearly stated by the Prime Minister:
"Malaysia should not be developed in the economic sense. It must be a nation that is fully developed along all the dimensions: economically, politically. socially, spiritually, psychologically, and culturally. We must be fully developed in terms of national unity and social cohesion, in terms of our economy, social justice, political stability, system of government, quality of life, social and spiritual values, national pride and confidence"

The Vision charts a journey towards industrialisation with a strong infrastructure in the information age with the ultimate aim to create an informationrich society. In order to comprehend further what it means to be an informationrich society, Ahmad Sarji (INTECH, 1996) has defined it at three different levels, which include the following:-

- At individual level, information-rich means having ease of access to a variety' of databases that can assist the person in his work and facilitates the running of his daily chores and improve the quality of his life.

- At institutional level, the advent of multimedia technologies integrating voice, animation, video, text, graphics and images can improve the packaging of training courses to be offered by training institutions.

- At the national level, it is a necessity to have an IT infrastructure that can support and sustain the development requirements.

Becoming an information-rich society by the year 2020 conjures an image of a society that thrives and develops around information for work. The establishment of this society is an important requisite in facing the challenge of moving towards an industrialised nation state and consequently will enable the country to prepare itself to face the information era. In his opening speech at the launch of Multimedia Asia ' 96 held in August 1996, the Prime Minister reiterated the Government's decision to move into the information technology industry with a single-minded approach developing the country using the new tools offered by the Information Age (Ahmad Sarji, 1993). 


\subsection{Computerisation in the Government}

Government is the third largest IT user after the banking and financial and manufacturing sectors, spending almost $\$ 240$ million in its projects in 1995 . The use of information technology as a management tool, productivity tool and strategic/competitive tool in the public sector is no longer a matter of choice but rather of compulsory. Computerisation in the public sector in Malaysia first started in 1965 and has since increased tremendously in the areas where data is highly structured and voluminous and the work is repetitive in nature. In the 1980s, it was used to assist in planning, monitoring, control and decision-making and in the 1990 s as a weapon to improve its competitiveness to meet the demands of globalisation. The trend in computerisation is depicted in Figure 1.

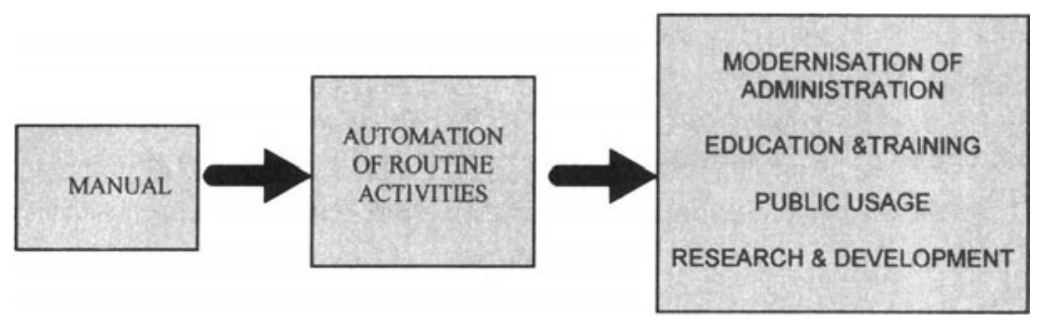

Figure 1 The trend in computerisation in the Government.

There are several objectives in setting up information systems (IS) in government, among which are :

- improving efficiency and accountability in government administration;

$\square$ enhancing managerial effectiveness;

$\square$ improving delivery of government services; and

$\square$ promoting both the availability and better access to information.

Information systems in this area can be further classified into three main categories, where each of these differ in their use and function (Venugopal, 1990):

- Management Information System (MIS) - use for automating basic processes in terms of transaction processing. Examples include payroll, accounting and revenue collection.

- Management Support System (MSS) - mainly use to satisfy the information needs of managers in supporting decision-making processes. Example includes database retrieval applications which can be used to support management decision.

- Strategic Information System (SIS) - use to support or shape competitive strategy of the organisation and have the functional capabilities for processing pre-defined transactions and providing facilities for query and analysis. 
The commitment of Malaysia in recognizing IT in enhancing productivity and competitiveness is witnessed in the increase of investment in IT during the Sixth Malaysia Plan from \$0.52 billion in 1990 to $\$ 1.52$ billion in 1995 (SMP, 1996) and expected to increase manifold in the next five years. During the Seventh Malaysia Plan (1996-2000), the main thrusts of IT development will be to :-

- widespread diffusion and application of IT within and across sectors to stimulate productivity and competitiveness and further improve the quality of life Ensure.

- Develop a national action plan to ensure a more systematic approach to manage IT development in the country.

- Expand IT education and training in line with the anticipated demand for ITrelated skills, knowledge and expertise.

- Review laws and regulations that restrain the development of IT.

- Promote the development of the local IT industry, in terms of design, and production of innovative products, system and services, to generate new growth opportunities as well as skills and employment in high-technology areas.

- Develop Malaysia into an IT hub with international IT companies operating from Malaysia.

- Enhance IT awareness among the population.

To date, a national action plan for IT is still under development. The plan in a summarised form as depicted in Figure 2 takes into account all the above aspects and customise them to eventually be developed into Malaysian IT culture. IT resources acquisition in the government and industry as well as individuals have been made much easier and affordable by the removal of tax on all computer equipment, in particular the multimedia hardware and software. A substantial amount of budget has also been allocated for IT purposes as stipulated in the Sixth and Seventh Malaysia Plan. Several committees have also been set up to review and making amendments to the existing laws and regulations in order to facilitate the adoption and implementation of the various IT programmes that have been carefully planned.

The organisations have no choice but to undergo changes to prepare themselves to create a more flexible and receptive milieu to new changes that may be created as a result of IT implementation in their operations. Traditional organisational structures are expected to change from the hierarchical and pyramidal beuracracy to flatter and leaner organisations having a network of key professionals. Universities, like organisations, will face the same need to redirect talent. The emphasis will be on providing highly trained knowledge-based scientific, engineering and technical personnel that make it possible to absorb new technologies. Any shortfall in this requirement will mean a slower pace of IT adoption. 


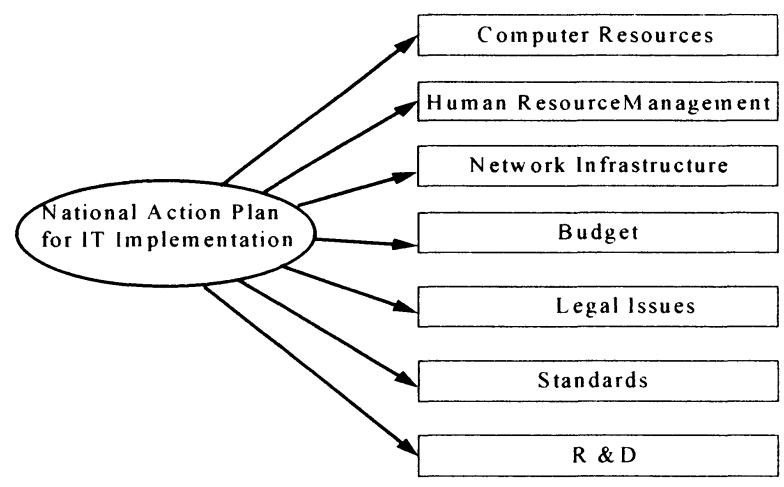

Figure 2 National framework for IT implementation.

In the Seventh Malaysia Plan, the Government has stated its commitment to place more emphasis promoting co-financing and joint programmes of research between industry and public sector institutions with a view to transferring research output for commercial and industrial applications.

\section{REVIEW OF IT INITIATIVES AND DEVELOPMENT}

Based on the focus areas in the Seventh Malaysia Plan, The National Information Technology Council (NITC) whose members are representatives from both the Government and the Association of Computer Industry Malaysia (PIKOM) has been given the mandate to formulate a national action plan to effect adoption and diffusion of IT in and to identify the undertakings and contributions of both the public and private sectors. Amongst others, the plan will chart the necessary initiatives to promote the development of Malaysia into an IT hub and will outline the scope, size and schedule of plans and programmes as well as identify the necessary infrastructure support in terms of education and training. Several of the IT initiatives are already in the implementation stage whilst the others are about to be launched soon. Major key players in the initiatives are as shown in Figure 3. Their respective role and involvement in the execution of various IT initiatives will be explained in sebsequent sub-sections.

Amongst the major initiatives covering several sectors in the government and industry are:

a) Development of information infrastructure

b) The Multimedia Super Corridor

c) IT in education

d) IT in manufacturing sector

e) The electronic commerce 


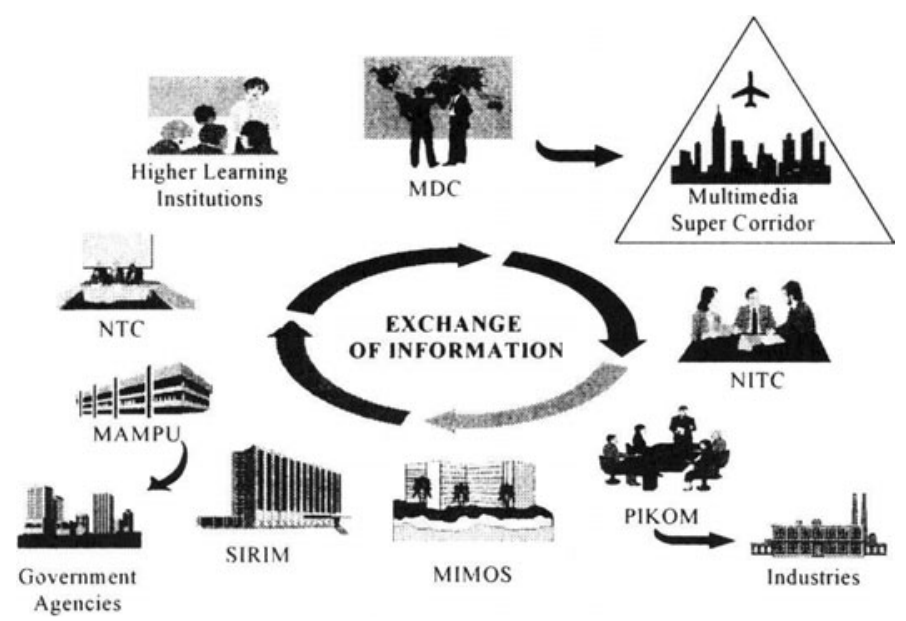

Figure 3 Major key players in the adoption and diffusion of IT.

\subsection{The Development of Information Infrastructure}

As evidenced in the IT Program of the Sixth Malaysia Plan (1991 -1995) where the development of information infrastructure is identified as one of the six areas to be implemented reflects the Government's commitment on the importance of establishing it. The Government efforts in building the various components of information infrastructure is summarised in Table 1.

For the purpose of connectivity among information systems and information exchange, standards play an important role. Open systems serves the need for such standards. A set of standards called Basic Technical Specifications (BTS) has been issued under the Public Sector Open Systems Programme in April 1992. All government agencies have to comply with the BTS when acquiring new computers and network facilities.

Table 1: Government's role in the development of information infrastructure

\begin{tabular}{|l|l|}
\hline $\begin{array}{l}\text { Components of } \\
\text { Information Infrastructure }\end{array}$ & \multicolumn{1}{|c|}{ Project Examples } \\
\hline & Open Systems \\
Standards & SITTDEC, MASTIC, SIRIMLINK, PORIMLINK, \\
Databases & CSL \\
Computer Facilities & \$239 million projects approved \\
Generic Software & Computerised Votebook, SAGA, SPM \\
Telecommunications & GITN, PSN \\
\hline
\end{tabular}

Source: MAMPU 1995 
The concept of information sharing should be practiced not only for the purpose of reducing maintenance cost but also to increase the service quality to the public. The Government's commitment to promote information sharing among government agencies and the public and private sector is supported with the establishment of these databases (Shafie, 1994):- SITTDEC (South Investment, Trade and Technology Data Exchange Centre), MASTIC (Malaysian Science and Technology Information Centre), SIRIMLINK (on-line database service provided by the Standards and Industrial Research Institute of Malaysia or SIRIM), PORIMLINK (on-line database service provided by the Palm Oil Research Institute of Malaysia or PORIM) and CSL (Civil Service Link). Electronic kiosks have also recently been set up to allow the public greater access to these databases.

Efforts were also undertaken to develop a standardised application of generic software. An example of generic software implemented by the government is the Standard Accounting System for Government Agencies known as SAGA. Pilots tests of this system conducted at five agencies have proven the viability of the daily closing accounts. The introduction of the standardised Micro Accounting System known as SPM in government agencies has enhanced the effectiveness in the management of costs of output produced. Utilisation of these generic software will facilitate the information sharing among government agencies.

Several government agencies have also made use of client-server technologies to facilitate the sharing of resources between their headquarters and branch offices nationwide. This has created a new environment where the processing of transactions are carried out as Enterprise Information Processing. This phenomena can be witnessed at the Department of Inland Revenue, the Ministry of Domestic Trade and Consumer Affairs and the Road Transport Department. Such operations enabled customers to enjoy services at the electronic counters available at the nearest branch office.

Telecommunication is the key element of Information Infrastructure and its importance is reflected in the interdependency of data processing and telecommunications in most information system, having information available in the right place at the right time, capturing basic data about daily operations as they occur, and allowing geographic dispersion of facilities and people. Malaysia is expected to spend $\$ 20$ billion to bring its telecommunication systems to world standards (Naisbitt, 1995). The installation of fiber-optic submarine systems will connect all major cities in Malaysia as part of the development of the information superhighway that will connect businesses and people more effectively. In the public sector, the Government has been given approvals worth $\$ 239$ million. These approvals have been granted for the procurement of software and hardware, telecommunication equipment, project management services and applications development, multimedia hardware and software and use of value added services.

The setting up of Public Service Network (PSN) in 1994 enables Government agencies to offer their counter services on-line to the general public using the computer and network facilities installed at post offices. Another project is the Government Integrated Telecommunication Network (GITN) that will be part of a 
mechanism that will reduce paperwork in public administration as well as part of an infrastructure for better delivery of government information services to the public. In time, it is entrusted to form the backbone of the public sector network capable of providing the whole range of network services towards attaining Vision 2020 goals.

Recently, the Government has set up the National Telecommunication Council (NTC) chaired by the Prime Minister. Members of the Council include the Deputy Prime Minister, the Minister of the Ministry of Energy, Telecoms and Posts, representatives from several ministries, representatives from major network providers, and IT experts from local universities and research bodies. NTC acts as an advisory body to the Government relating to the development of telecommunication in the country, in particular, the establishment of the integrated network to support the Multimedia Super Corridor. NTC has also the responsibility to promote local industry to manufacture network and telecommunication products that meet the international standards (Komputer, 1996). At the same time, training and research and development in the telecommunication-related area will also be upgraded. MIMOS, an organisation formerly owned by the Government was recently corporatised as a step to enable the organisation to be more effective and competitive in providing Internet and other network services.

Thus far, the adoption and diffusion of new information technologies in government agencies have been planned meticulously and implemented in a systematic manner (see Figure 3). This is done using the pilot project approach in selected agencies prior to their full implementation in all government agencies. To ensure these programmes are successfully implemented, clear guidelines have been issued and the relevant personnel trained (Ahmad Sarji, 1993). In so far, several guidelines that may directly or indirectly related to IT have been issued. They are the Development Administration Circular No. 3 of 1991, the Guidelines on Migration to Open Systems, the Open Systems Basic Technical Specifications, the Multimedia Act 1997, and the Total Quality Management Programme. Several concepts with the aim to improve the quality of the Civil Service are currently being introduced. These concepts include Business Process Re-engineering, TQM, paper-less administration using Electronic Data Interchange (EDI) technology, image processing, and interorganisational sharing of information.

Surveys and other forms of evaluation are conducted periodically to gauge feedback from the involved agencies. Data gathered are then analysed and later used to monitor and improve the adoption programmes. The Malaysian Administrative Modernisation and Management Planning Unit (MAMPU), a body under the Prime Minister's Department is responsible to conduct the surveys and assessments of the programmes. MAMPU is also responsible in providing consultancy services to government agencies in the execution of their computerisation programmes as well as coordinating the procurement of their computer resources. 


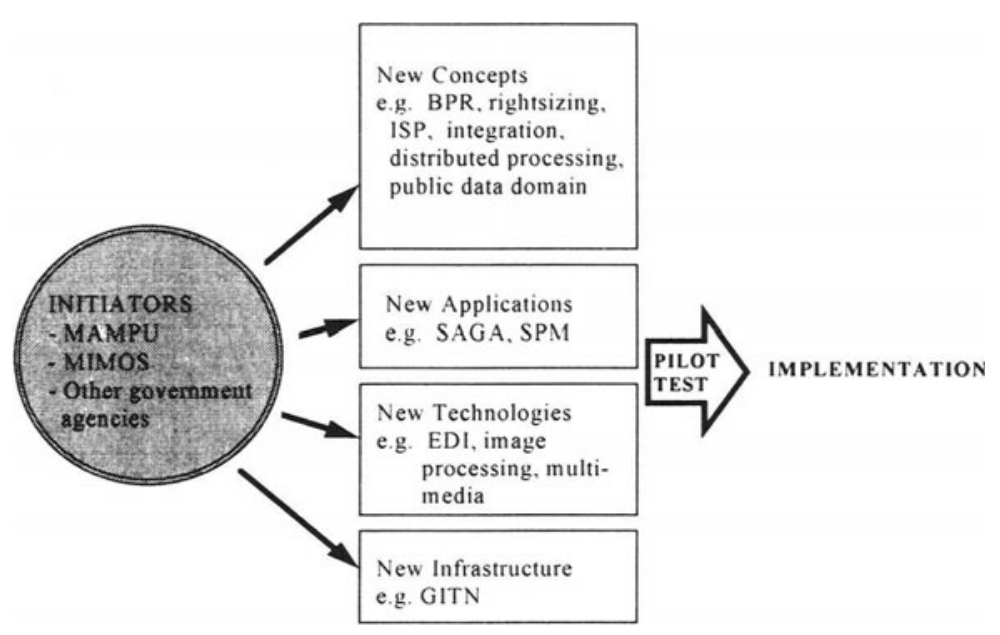

Figure 4: The Adoption and diffusion of IT programme in the Public Sector

\subsection{The Multimedia Super Corridor}

Three mega projects which become the current focus of the country are now on their way and are scheduled for completion in 1998. Namely, they are Putrajaya (the new Federal Government Administrative Centre), the new Kuala Lumpur International Airport (KLIA) and Kuala Lumpur City Centre (KLCC). All these will act as major consumers of multimedia products and services. Known as Multimedia Super Corridor (MSC), it covers an area of $15 \mathrm{~km}$ by $40 \mathrm{~km}$ and will be a showcase of national resources and symbol of a new era which will see Malaysia attaining developed nation status (Muhammad, 1995). Putrajaya is carefully planned as a city embodying the concept of a fundamental trinity of relationships: Man and his Creator, Man and his fellow man, and Man and his environment. As an intelligent city, Putrajaya will use the state-of-the-art IT to showcase electronic governance and public administration at its best. The applications being developed for this new seat of the government will act as models for adoption by other government agencies at local level as well as for export to other developing nations. KLIA will also act as the vehicles for the development of IT applications for airport management services. The KLCC is a self-contained city with infrastructure that emphasise on access and efficient transportation. KLCC will be served by the Light Rapid Transit (LRT), roadways and other proposed inter-city system. Intelligent buildings amidst a large rest and recreation park will be featuring KLCC (MSC, 1996). The Multimedia Development Corporation $(\mathrm{MDC})$ is a government-owned company set up to manage and promote the MSC. 
The MSC will be a "testbed" for the new roles of government, new cyberlaws and guarantees, collaboration between government and companies, companies and companies, new broadcasting and new types of entertainment, education, delivery of healthcare, and application of new technologies. A key component of the MSC is a collection of seven key applications. The applications are electronic government, telemedicine, research and development cluster, worldwide manufacturing web, borderless marketing centre, multimedia funds haven and the world's multipurpose smart card.

To ensure the success of the MSC, the Bill of Guarantees for MSC companies (INTECH, 1996) was introduced to provide a most crucial incentive for companies to participate in the MSC. A high degree of information technology transfer is expected to occur through active participation of and collaboration among these companies. Hence, the Bill among others will upgrade the proliferation of IT and multimedia in terms of usage and development by ensuring the following:

- Multimedia and IT is the priority sector for achieving Vision 2020 and the MSC will be home to Malaysia's leading-edge multimedia development.

- The MSC will have the best environment in Asia by creating MSC-specific laws, policies, and practices.

- MSC companies will have access to a workforce of sufficient size and skills.

- The MSC will become a regional centre of excellence in multimedia education, research, and leading-edge applications and this will be soon realised with the establishment of University of Multimedia.

- The MSC will become a leader in multimedia regulations, "cyberlaws" for using IT to deliver value in new ways such as telemedicine, distance learning, electronic commerce, and electronic government.

Companies committing to the MSC will be further given incentives such as corporate tax exemption for five to ten years depending on proposed applications to be performed within the MSC. Additional incentives will also include an opportunity for MSC companies to sit on advisory panel that will provide direct input to the Prime Minister on the environment provided within the MSC. The MSC has insofar attracted the interest of major local and world investors such as AT\&T, EDS, Fujitsu, IBM-ISCC, NEC, Netscape, NTT, Sony, Siemens, Microsoft and Telekom Malaysia.

The setting up of the MSC also sees cooperation between local and foreign companies in promoting R\&D. For a start, NTT would team up with Telekom Malaysia as well as with MIMOS and the Ministry of Energy, Telecoms, and Posts to carry out research on three areas which are Social and Institutional Design; Open Design; and IT Technology Design. Initially, these areas would be worked on separately but they might be consolidated at a later stage. 
Critical success factors (CSF) for the MSC

The following critical factors to ensure the success of the MSC have been identified as follows (INTECH, 1996):

\begin{tabular}{|c|c|}
\hline CSF & Elaboration \\
\hline Applications & $\begin{array}{l}\text { Right kind applications based on multimedia technology are } \\
\text { crucial to create new markets and cater for existing ones. }\end{array}$ \\
\hline Access & $\begin{array}{l}\text { Successful partnership between the public and private sectors, } \\
\text { geographical, cultural, and capital access are the contributing } \\
\text { factors to the MSC. }\end{array}$ \\
\hline $\begin{array}{l}\text { Local IT } \\
\text { industries }\end{array}$ & $\begin{array}{l}\text { A special area for small IT cottage industries of the future needs } \\
\text { to be created to nurture the country's own workforce as well as } \\
\text { individual entrepreneurship. The advancement of the industry } \\
\text { will be stimulated by encouraging new hardware and software } \\
\text { product development. During the Seventh Plan period (1996- } \\
2000) \text {, the software industry will be further developed into an } \\
\text { exporter of software products and services. The hardware } \\
\text { industry will focus on high volume and high value-added } \\
\text { manufacturing as well as the development of own-brand } \\
\text { computer components and peripheral products. }\end{array}$ \\
\hline $\begin{array}{l}\text { Shared } \\
\text { vision }\end{array}$ & $\begin{array}{l}\text { A shared vision attitude towards the MSC needs to be adopted } \\
\text { by the Malaysian people to reduce resistance and induce } \\
\text { support for its future growth and success. }\end{array}$ \\
\hline $\begin{array}{l}\text { Education } \\
\text { system }\end{array}$ & $\begin{array}{l}\text { Shared vision can only be achieved through the revamption of } \\
\text { the education system. The outcome of the revamped education } \\
\text { will lead to the ability of the future generation to adopt "we } \\
\text { learn how to learn" attitude so that they can continue their } \\
\text { education throughout their lives. }\end{array}$ \\
\hline Attitude & $\begin{array}{l}\text { The country's right attitude towards making the MSC a success } \\
\text { will become its competitive advantage. For example, the } \\
\text { Government's initiation of the Bill of Guarantee is the first step } \\
\text { towards removing political and business barriers which in turn } \\
\text { will attract foreign investment for the MSC. }\end{array}$ \\
\hline People & $\begin{array}{l}\text { The MSC must also create an environment for the participating } \\
\text { companies to improve the skills and knowledge of their human } \\
\text { resource as to ensure smooth adoption of new technologies in } \\
\text { their workplace. }\end{array}$ \\
\hline $\begin{array}{l}\text { Guaranteed } \\
\text { bandwidth }\end{array}$ & $\begin{array}{l}\text { To function successfully, reliable bandwidth is critical to cater } \\
\text { for day-to-day robust operations and processes in the MSC. }\end{array}$ \\
\hline
\end{tabular}

Other important factors include political stability and continuity, and affordability. 


\subsection{IT in education}

For the last ten years in the education sector, major initiatives have been undertaken to improve all aspects of learning and teaching at all levels of education through the use of IT. For example, the development of the Information Superhighway and MSC provide the necessary infrastructure to upgrade the education system to provide the country with adequate IT skills, experience, and expertise. In Higher Learning Institutions, IT courses are no longer confined to the traditional computer science and management of information systems but have ventured out to areas like internetworking and multimedia. Twinning programmes are in abundance in private colleges offering double major programmes which inculcate IT and non-IT disciplines to create IT professionals adept in a non-IT industry.

To support the growth of MSC, the Education Ministry is leading several initiatives to increase the number of engineers graduating every year and to promote the role of multimedia in education. For a start, University of Telecom sponsored by Telekom Malaysia was recently established to produce telecommunication experts to meet ever-growing local demands. This will be soon followed by the establishment of technology schools and Multimedia University whose campus will be located in the Multimedia Super Corridor.

In schools, through the Computer-In-Education (CIE) programme, students are exposed to computer literacy programmes that will enable them to manipulate the computer as a tool. For example, all schools within the MSC will be connected to the Internet by 1998 and the rest of the country will follow. Even at the pre-school level there are programmes run by private organisations which are dedicated to instill in children a variety of technological skills. The launching of the first Malaysia East Asia Satellite (Measat) promises to bring new distance learning technologies. Telekom Malaysia's EDUNet, a nationwide fibre-optic and digital microwave network, facilitates video-conferencing between and within the institutes of higher learning.

The tax abolishment on computer equipment and software seen earlier this year has also encouraged the public to invest in computers and computer peripherals and software for education and edutainment purposes.

Universities and colleges have also upgraded their campus networks to fully utilise the latest developments in information technology in their efforts to upgrade the quality of education, learning, and administration. In addition, the Joint Advanced Research Integrated Networking (JARING) network has also enabled staff and students of these universities to access information residing in international databases, through Internet, for research purposes. In 1995, several universities offered several courses such as computer science and engineering through distance learning programmes. At present, plans are underway to establish virtual campuses as part of twinning programmes between local and overseas universities. As an extension to the computer-in-education programmes, EDUNet was introduced in 1995 as a pilot project involving 50 secondary schools. EDUNet 
facilitated communication and interaction between students and teachers as well as access to educational information between, both within and outside the country, through the computer network connected to Internet. Consequently, teachers will need to change their role in the electronic classroom from being information providers to counsellors in order to help the students know how to select information sources, to make judgments about what they are downloading.

The measure of the success of the revamped education in the year 2020 will be the number and quality of the people who can add value to information.

\subsection{IT in Manufacturing Sector}

For the manufacturing sector, the majority of IT applications were in the areas of accounts and finance, payroll, word processing, personnel records and inventory. However, there were indications that manufacturing firms planned to increase the use of IT in more strategic functions such as product design, quality control, process planning, production, and material planning. These functions will be enhanced with the use of computer-aided design (CAD), computer-aided manufacturing (CAM), and computer-aided engineering (CAE) as well as robotics.

During the Sixth Malaysia Plan period, efforts were undertaken to promote, expand and upgrade IT applications and advanced manufacturing technology in the industrial sector. Government agencies such as the Standards and Industrial Research Institute of Malaysia (SIRIM) and the Malaysian Institute of Microelectronics System (MIMOS) complemented these efforts through specific programmes to introduce and promote the usage of new technologies incorporating IT. SIRIM provided training in CAD/CAM/CAE while MIMOS undertook research and development and provided training in Very Large-Scale Integrated Circuit (VLSI) design. In addition, MIMOS assisted industries in software development, product development and printed circuit board (PCB) design, fabrication and assembly activities as well as in the provision of IT services. The shortage of relevant industrial and technical skills especially in small medium enterprises (SMIs), however, constrained in the wider use of IT.

\subsection{The electronic commerce}

Keen (1991) has predicted that Electronic Data Interchange (EDI) will become a common application in the $90 \mathrm{~s}$. EDI becomes an important tool to achieve a paperless society. For example, the introduction of EDI in the Government administration has succeeded in reducing the use of papers in several public agencies. Parts of the import and export procedures of the Royal Malaysian Customs and Excise Department have been successfully automated, thus cutting short the processing time for goods clearance. The use of EDI will be extended to the Subang International Airport and subsequently to all entry points via sea, land or air. 
The catalytic role played by the Malaysian Civil Service in the dissemination of information in the Asian region has become increasingly important. Six Asian countries have agreed to conduct a joint feasibility study for the use of EDI by their respective Customs authorities to exchange import and export documents. To effect coordination, Malaysia has been selected to chair the Inter-Networking Implementation Committee and the Customs Working Group under the auspices of the Asia EDIFACT Board (ASEB) of which Malaysia is one of the Deputy Chairmen.

\section{DISCUSSION AND CONCLUSION}

Many modernisation programmes have since been introduced over the years through the use of computers and information technology to bring about changes not only in the Government but also the industry. Since the inception of the computerisation programme, the public have benefited a great deal. For example, individuals can benefit from the automated offices of government departments, where a multiplicity of services can be offered one-stop. On the business front, businesses can use current information generated by computers to deal with fastchanging market and well-informed customers. Similarly, at the institutional level, the advent of multimedia technologies can improve the package of training courses to be offered by training institutions.

While all the above development are well and fine, it is found that IT is not used strategically enough for a developing country like Malaysia to progress into the next millennium. Thus, in early 1991, Malaysia has taken a bold step towards achieving developed country status by setting out strategic directions for the country for the next couple of decades. A single minded "Malaysian style" approach in developing the country by moving into the information technology industry can be seen as the country's firm in using IT as a strategic tool to fast achieve the status. Multi-faceted short- and long-term IT initiatives have been carefully planned to enable the country to exploit the unlimited potential of IT. The success of the initiatives especially the Multimedia Super Corridor megaproject will not only be the milestone for the continuing growth of IT in the country but will also reflect the ability of Malaysian people to overcome the political, social, and mental barriers to leapfrog into the information age.

While it is our aspiration to be information-rich, we have to acknowledge that the advent of the information age has also brought along with it new issues and challenges. These are not purely technical concerns but those ethical considerations that need to be addressed by various parties, namely, managers, legislators, and professionals. For example, in the dissemination of government information to businesses, the professionals and the general public (as in the case of electronic kiosk), what should be the appropriate pricing policy? How do we make information available to the poor for their social and economic betterment? How do we incorporate IT in the spiritual and cultural development of our society as envisioned in Vision 2020? At the international level, how do we address 
transborder data flow concerns which also impinge on social, economic, national unity and security and sovereignty issues? In other words, despite the obvious benefits, information technology also has costs.

There are also legal issues need to be resolved arising from widespread computerisation. For instance, in the usage of EDI for trade facilitation, how does one determine the authenticity of users and hence the authenticity of documents being sent across the networks? Indeed, the rapid pace of IT exploitation can outstrip the existing legal and security practices. While it is necessary that we reexamine the well-established legal processes, workaround solutions need to be immediately found if we are to substantially benefit from these new IT initiatives and technologies.

\section{REFERENCES}

Ahmad Sarji A.H. (1993) The Changing Civil Service: Malaysia's Competitive Edge. Pelanduk Publications, Kuala Lumpur.

INTECH (1996) Corridor to the Future, IN-TECH,The Star (Tuesday, August 6), Kuala Lumpur, p.3.

Keen, P. G. W. (1991) Shaping the Future: Business Design Through Information Technology. Harvard Business Scholl Press.

Komputer (November 6, 1996), Berita Harian Publishing, Kuala Lumpur.

MSC (1996), Malaysia's Multimedia Super Corridor. http://www2.jaring.my/msia/ $\mathrm{rnd} / \mathrm{msc} . \mathrm{html}$

Muhammad Z. (1995), Putrajaya - New Seat of Government. Khidmat, December Issue, MAMPU \& Berita Publishing Sdn. Bhd., Kuala Lumpur.

Naisbitt, J. (1995) Megatrends ASIA - The Eight Asian Megatrends That Are Changing The World. Nicholas Brealey Pub. Ltd.

Shafie H. \& Tan K.I. (1994) Information Infrastructure for The Government. Khidmat, May Issue, MAMPU \& Berita Publishing Sdn. Bhd., Kuala Lumpur.

SMP (1996) Seventh Malaysia Plan 1996-2000. Percetakan Nasional Malaysia Berhad., Kuala Lumpur.

Venugopal, P. (1990) In the Pursuit of Excellence. Khidmat, December Issue, MAMPU \& Berita Publishing Sdn. Bhd., Kuala Lumpur. 
Vision2020 (1991)- Proceedings of National Seminar on Vision 2020. 5-7 December, organized by Socio-Economic Research Unit.

Zainuddin D. (1996) Managing Technology for Growth and Development. A speech text delivered in Kuala Lumpur on 21 June 1996.

\section{ABOUT THE AUTHORS}

M. Kamsah is currently pursuing her Ph.D. in Information Systems at the Information Systems Research Centre (ISRC) at Salford. Prior joining ISRC, she worked as a Systems Analyst for five years at the Prime Minister's Department, Malaysia, a training facilitator at the National Institute of Public Administration for two years, followed by a lecturing position at University of Malaya, Kuala Lumpur. Miss Kamsah received her undergraduate degree in Science, postgraduate Diploma in Systems Analysis, and MSc in Computer Science from Toyohashi University of Technology, Japan. Her research interests include Electronic Commerce, Multiview Methodology and Soft Systems Methodology.

S. Mokhtar is lecturer at University of Malaya, Kuala Lumpur. She is currently on study leave to enable her to pursue her Ph.D. studies in Malaysia in the area of Interorganisational Information Sharing among public agencies. Miss Salimah completed her bachelor and Masters degrees in Computer Science at Washington State University, USA.

Trevor Wood-Harper is Professor of Information Systems. He is also Director of a multidisciplinary Information Systems Research Centre at Salford. He set up and now co-directs one of the few doctoral schools in the country which is a combination of both American and European Ph.D. educational styles. Trevor Wood-Harper has published and edited numerous books as well as over one hundred research articles on a wide range of topics including Information Systems Development, Information Systems Ethics and the Multiview Methodology. 